\title{
PERANAN EKOLOGIS SPONS \\ PADA EKOSISTEM TERUMBU KARANG
}

\author{
Oleh \\ Tri Aryono Hadi ${ }^{1}$
}

ABSTRACT

ECOLOGICAL ROLES OF SPONGES IN CORAL REEF ECOSYSTEMS. Sponges are one of main reef benthic components which is quite abundant and worldwide distributed. Due to its unique characteristics, such as filtering water column, possessing pores throughout the body, and producing metabolite compounds, sponges play important roles in marine ecosystems. In coral reef ecosystems, the roles are very complex, including facilitating nutrient cycles, stabilizing/eroding calcareous substrates, hosting many types of marine organisms, providing protection to its symbions, competing with other marine benthos in structuring the reefs and as a bioindicator. In this case, sponges can be illustrated as a mediator between abiotic and biotic factors, thus material and energy transfers in the coral reef ecosystems can be boosted. Therefore, it is essential to monitor sponge communities in the reefs considering that its immense roles cannot likely be replaced by other marine organisms.

\section{PENDAHULUAN}

Spons adalah biota bentik yang banyak ditemukan pada semua ekosistem air laut dan tawar. Di ekosistem air laut, spons paling banyak ditemukan di habitat terumbu karang, padang lamun dan mangrove (Wulf, 2008; Diaz \& Rutzler, 2009; De Goeij et al., 2013). Adapun di ekosistem air tawar, spons masih dapat ditemukan di daerah aliran sungai ataupun di danau-danau dengan kelimpahan dan diversitas yang rendah (Manconi \& Pronzato, 2008). Distribusi spons yang luas di banyak tipe habitat disebabkan oleh cara hidup spons yang menyaring air secara efektif sehingga tidak memerlukan banyak energi, dan larvanya mampu tumbuh pada semua tipe substrat (Van Soest et al., 2012). Keberadaannya

\footnotetext{
1) Pusat Penelitian Oseanografi-LIPI
}

yang bersifat kosmopolitan perlu diketahui peranannya dengan baik sehingga dapat menjadi bahan masukan dalam pengelolaan ekosistem. Dalam makalah ini akan dibahas secara spesifik peranan ekologis spons pada ekosistem terumbu karang, mengingat ekosistem ini mempunyai fungsi ekologis dan ekonomis yang tinggi namun rentan terhadap perubahan lingkungan.

\section{FUNGSI EKOLOGIS}

Fungsi ekologi spons di ekosistem terumbu karang dapat dikaitkan dengan faktor abiotik dan biotik. Faktor abiotik berkaitan dengan siklus nutrient, bioreosi dan konsolidasi substrat dan bioindikator pencemaran. Sedangkan faktor biotik 
berkaitan dengan kemampuan spons sebagai inang, umpan dan pelindung serta kompetisi dengan biota bentik lainnya.

\section{a. Siklus nutrien}

Spons laut mempunyai kemampuan menyaring air dengan sangat efisien yaitu sekitar 10 kali volume tubuhnya tiap jam (Hooper, 2003). Dalam menyaring air, spons tidak hanya mencerna nutrient, namun juga menggunakan oksigen terlarut untuk metabolismenya. Dalam hal ini, spons mempunyai kemampuan mencerna phycoplankton (sumber partikulat karbon organik (Particulate Organic Carbon) yang kemudian dapat membersihkan kolom air dari blooming. Selain itu, spons juga dapat memanfaatkan sumber karbon terlarut (Dissolved Organic Carbon) yang dihasilkan oleh rumput laut dan karang. Makanan yang dicerna tersebut kemudian akan digunakan untuk metabolisme, pembentukan metabolit sekunder, pembentukan sel-sel baru ataupun skeleton. Siklus karbon tidak hanya berhenti di spons, melainkan ke tropik level yang lain seperti biota detrivus ataupun karang yang memanfaatkan POC yang berupa patahan-patahan kecil/halus kumpulan dari sel-sel tubuhnya (Gambar 1) (de Goeij et al., 2013).

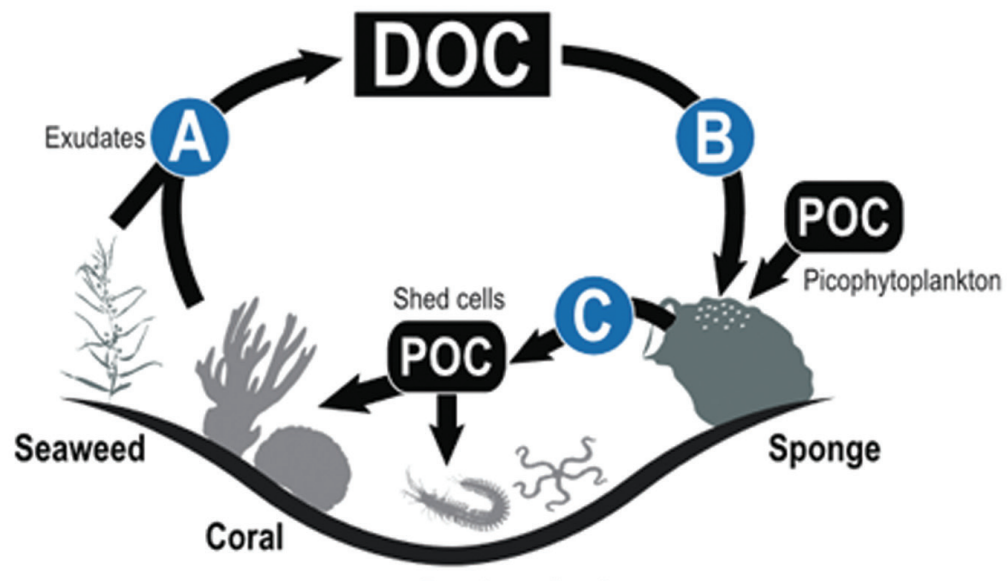

Detritus feeders

Gambar 1. Siklus karbon oleh spons dalam eksosistem terumbu karang. A : rumput laut dan karang memproduksi DOC yang labil, B : Spons menkonsumsi DOC, C : spons menghasilkan POC (de Goeij et al., 2013).

Spons juga mempunyai peranan yang penting dalam siklus silikat $(\mathrm{Si})$ karena spons mampu mengakumulasi silikat sebagai bahan komponen penyusun skeletonnya (Treguer et al., 2013). Dalam hal ini, spons sebagai penyerap silikat dan spons mempunyai kemampuan hidup yang lama sehingga siklus silikat cenderung lebih lambat. Lebih lanjut, spons juga dapat menyebabkan suatu perairan kekurangan silikat namun hanya dalam skala lokal (Maldonado et al., 2005). 
Sebagaimana hewan pada umumnya, spons menggunakan oksigen untuk proses respirasi. Spons diketahui mempunyai konsumsi oksigen rata-

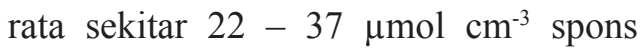
per hari (Hoffmann et al., 2008). Spons juga dilaporkan dapat mengakibatkan suatu perairan kekurangan oksigen yang bersifat lokal, terutama pada gua dalam air yang dihuni banyak spons (Richter et al., 2001). Meskipun demikian, belum pernah dilaporkan terjadi kekurangan oksigen pada ekosistem terumbu karang akibat spons yang melimpah.

Nitrogen di ekosistem terumbu karang umumnya memiliki konsentrasi yang rendah dan terikat dalam partikel atau dalam senyawa organik terlarut. Nitrogen anorganik terlarut harus melalui serangkaian proses transformasi terutama oleh bakteri sebelum akhirnya dapat dimanfaatkan untuk organisme lainnya (Granger et al., 2008; Kaiser \& Benner, 2008). Siklus nitrogen di dalam spons terjadi ketika bakteri yang berasosiasi menggunakan nitrogen terlarut, dan saat spons mencerna cyanobacteria yang mengikat nitrogen bebas dari atmosfer (Hoffmann et al., 2009; Fiore et al., 2010). Tingkat konsumsi nitrogen pada spons adalah bervariasi namun berkisar antara 3-13 nmol N g dry $\mathrm{wt}^{-1} \mathrm{~min}^{-1}$ (Jimenez \& Ribez, 2007).

Kelimpahan spons di ekosistem terumbu karang sangat berkaitan dengan konsentrasi nutrien dan substrat yang tersedia (Bell, 2008). Dalam ekosistem terumbu karang, spons diketahui mampu menempati sekitar $40 \%$ substrat yang tersedia (Schmahl, 1990). Meskipun pada umumnya kelimpahannya tidak terlalu tinggi, kemampuan spons dalam mengontrol konsentrasi nutrien dapat memengaruhi distribusi dari biota-biota lain, seperti makroalga, ikan dan bahkan karang (Pawlik et al., 2016).

b. Pengaruh pada Substrat

Dalam perkembangan ekosistem terumbu karang, proses akresi dan bioerosi terumbu mempunyai peranan penting. Spons diindentifikasi melakukan proses bioerosi pada terumbu yaitu memproses kalsium karbonat padat menjadi fragmen-fragmen kecil dan partikel halus, sehingga nantinya akan berpengaruh (menurunkan) pada produksi sedimen dan (mengurangi) kekuatan struktur terumbu (Rutzler, 1975). Proses bioerosi umumnya dilakukan oleh spons dari Family Clionaidae yaitu dengan melibatkan sel penggores dan proses kimia yang melibatkan metabolit asam. Lebih lanjut, famili ini mampu melakukan proses bioerosi dengan laju mencapai 5.1 $\mathrm{kg} \mathrm{CaCO} \mathrm{m}^{-2}$ thn ${ }^{-1}$ (Nava \& Carballo, 2008), sedangkan proses kalsifikasi karang batu di ekosistem terumbu karang hanya berkisar $1.51 \mathrm{gr} \mathrm{CaCO}_{3} \mathrm{~cm}^{-2} \mathrm{thn}^{-1}$ (De'ath et al., 2009). Hal ini akan menjadi problem mengingat kecepatan bioerosi oleh spons lebih tinggi dibandingkan proses kalsifikasi karang sehingga dikhawatirkan akan menimbulkan efek negatif jangka panjang.

Spons mempunyai peranan yang positif dalam membangun terumbu yaitu salah satunya dengan menggabungkan patahan-patahan karang (rubble) sehingga menjadi lebih stabil dan memungkinkan untuk ditempati oleh 
larva karang untuk menempel (Wullf \& Buss, 1979). Spons membutuhkan waktu untuk menggabungkan patahan karang sekitar 7 bulan (Wullf, 1984). Hal ini terlihat ketika terjadi fenomena badai besar (cyclone), tsunami dan kejadian akibat bom, akan ditemukan banyak patahan karang yang belum ditumbuhi apapun, kemudian cryptic dan encrusting spons akan mulai muncul dan bekerja menggabungkan patahan-patahan tersebut (Bell, 2008).

c. Spons sebagai inang (host), umpan dan pelindung

Spons dikenal mempunyai kemampuan berasosiasi dengan banyak organisme dari berbagai macam tipe, mulai dari mikroba hingga organisme multiseluler komplek (Marliave et al., 2009; Sabdono, 2011). Hal ini membuat spons sebagai salah satu penyumbang biodiversitas tertinggi di ekosistem terumbu karang. Meskipun demikian, kompleknya asosiasi menyebabkan banyaksifatasosiasibelumdapatdiketahui dengan jelas. Spons memproduksi banyak jenis metabolit sekunder yang dapat menjadi media interaksi spons dengan organisme lain (Schmidt, 2008). Selain itu, pori-pori spons juga mampu menjadi tempat yang baik bagi biota-biota kecil untuk berlindung ataupun memperoleh makanan dari air yang masuk (Henkel \& Pawlik, 2011).

Produktivitas primer yang tinggi dapat mencerminkan bahwa ekosistem tersebut sangat subur. Spons mampu memfasilitasi produktivitas primer ekosistem terumbu karang yaitu dengan adanya simbiosis dengan organisme fotosintesis, baik itu bakteri maupun mikroalga bersel satu. Simbion akan melakukan proses fotosintesis dan imbalannya spons mendapatkan suplemen nutrisi (Rutzler,1990). Diperkirakan jumlah produk fotosintesis yang disumbangkan sekitar $48-80 \%$ dari total energi yang dibutuhkan spons (Wilkinson, 1986). Oleh karena itu, kelimpahan spons di suatu area terumbu karang dapat mencerminkan tingkat produktivitas primernya. Meskipun demikian, simbiosis ini dipengaruhi oleh kadar nutrien dimana pada area terumbu yang jauh dari pantai dengan kadar nutrien yang rendah, simbiosis ini akan lebih sering terjadi pada spons (Wilkinson, 1987).

Selain produktivitas primer, produktivitas sekunder juga dapat meningkat seiring dengan melimpahnya spons. Adanya pemangsa alami spons (ikan, opisthobranchs, krustasea, moluska dan ekinodermata) akan menyalurkan energi makanan ke tingkat tropik level yang lebih tinggi, sehingga akan meningkatkan produktivitas sekunder (Bell, 2008). Pemangsa spons akan berbeda untuk tiap region; sebagai contoh bintang laut dan nuribanch adalah pemangsa utama spons di daerah temperate dan Antartika (Peter et al., 2009). Ikan menjadi pemangsa yang paling utama di wilayah tropis terutama dari famili Scaridae (Parrotfishes) dan Pomachantidae (Anglefishes) dan hal ini menjadikan komunitas spons lebih dikendalikan oleh tropik level di atasnya (top down effect) daripada dikendalikan 
oleh tropik level di bawahnya, yaitu ketersediaan makanan (bottom up effect) (Pawlik et al., 2013).

Berbeda dengan karang yang hanya menjadi inang bagi mikroalga bersel satu (zooxanthellae), karateristik spons yang berongga dan jaringan mesohil yang kaya sumber karbon merupakan mikrohabitat yang sangat mendukung untuk biodiversitas ekosistem terumbu karang. Sebuah penelitian menemukan lebih dari 2000 individu yang berasosiasi dengan spons encrusting (Mycale microsigmatosa) yang terdiri dari 70 species dan 9 phyla (Ribeiro et al., 2003). Sedangkan penelitian lain mampu menemukan sekitar 100 species yang berasosiasi dengan spons Verongia aerophoba di Laut Aegean Utara (Voultsiadou-Koukoura et al., 1987). Beberapa biota yang berasosiasi tidak menjadikan spons sebagai inang untuk keseluruhan siklus hidupnya, melainkan hanya untuk tahap juvenil seperti
Ophioridea (Ophiotrix fragilis) (Turon et al., 2000).

Substrat yang tersedia dalam terumbu karang yang sehat akan selalu sedikit karena sudah ditumbuhi oleh biotabiota bentik, terutama karang. Terbatasnya substrat dan meningkatnya kompetisi antar sesama bentik, menyebabkan permukaan spons menjadi tempat untuk penempelan banyak jenis biota bentik meskipun diketahui spons mampu memproduksi metabolit sekunder untuk proteksi. Sebagai contoh, spons Agelas clathrodes yang ditemukan melimpah di Indo-Pasifik diketahui menjadi substrat (terutama bagian permukaan) bagi cacing serpulid, Ascidian, calcareous alga dan bahkan Briozoa (Bell, 2008). Selain itu, timun laut Synaptula lamperti ditemukan melimpah di permukaan barrel spons (Tan, 2010). Meskipun biota bentik yang menempel bervariasi, asosiasi ini dapat dikategorikan bersifat spesifik spesies atau spesifik mutualisme (Bell, 2008).

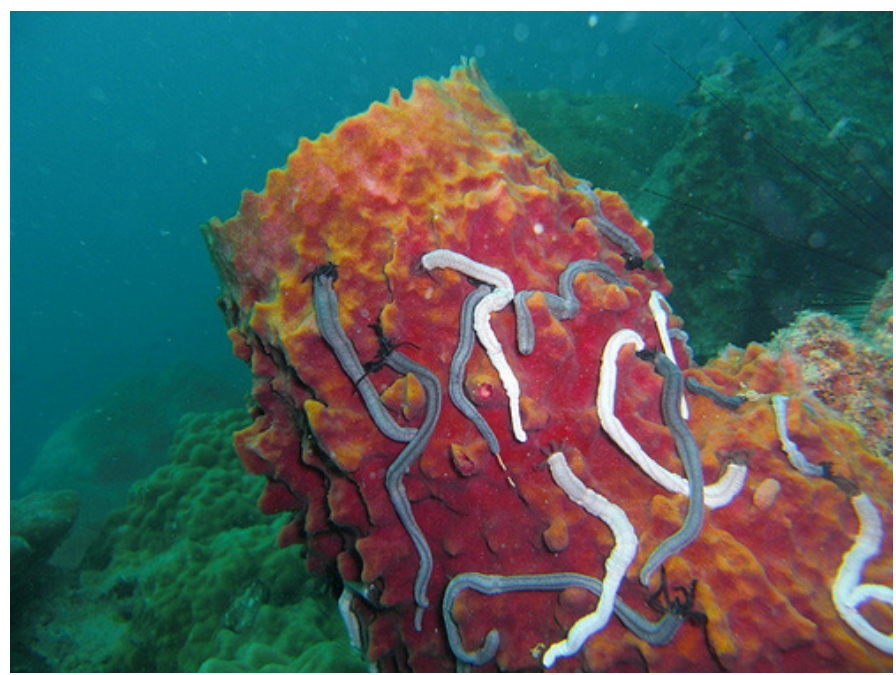

Gambar 2. Synaptula sp. pada permukaan spons (Puchner, 2013). 
Sebagai inang, spons juga memberikan perlindungan terhadap biota yang berasosiasi. Sebagai contoh, kematian bivalvia akibat pemangsa alaminya (bintang laut) ditemukan menurun ketika bivalvia (Arca noae) ditumbuhi spons encrusting (Crambe crambe) yang menghasilkan metabolit sekunder yang mampu mengusir predator bivalvia (Marin \& Belluga, 2005). Banyak spons juga menjadi tempat perlindungan bagi bintang mengular (Ophiothela spp) baik jantan maupun betina dan bahkan mampu meningkatkan fertilisasi biota tersebut (Henkel \& Pawlik, 2011). Selain itu, spons juga mampu memberikan efek kamuflase, seperti pada karapak dari kepiting (Libidodaea granaria) yang coraknya menyerupai tipe substrat yang dominan sehingga akan mengelabuhi mangsanya (Schejter \& Spivak, 2005).

d. Spons sebagai kompetitor bentik

Spons dikenal sebagai salah satu kompetitor utama karang batu di ekosistem terumbu karang. Fenomena ini lebih jelas terlihat di daerah temperate dimana musim-musim tertentu memacu pertumbuhan spons. Pada musim semi dan panas (April - Desember), spons tumbuh lebih cepat dan menjadi agresif (terutama tipe encrusting) sehingga mampu berkompetisi lebih baik daripada karang hidup atau biota bentik lainnya, seperti calcareous algae, Brozoans dan Hidroids. Lebih lanjut, pada musimmusim berikutnya dimana suhu perairan mulai menurun, spons tumbuh lebih lambat dan akan terjadi retraksi jaringan sehingga substrat yang sebelumnya tertutupi spons akan terbuka kembali.
Menariknya, arah dari pertumbuhan spons tidak sama sepanjang tahun sehingga substrat yang dulunya pernah tertutupi belum tentu akan ditutupi kembali di tahun berikutnya (Bell, 2008).

e. Spons sebagai bioindikator

Meningkatnya bahan pencemar di laut akan mengakibatkan akumulasi baik itu di substrat maupun di biota perairan. Karakteristik spons sebagai penyaring makanan dan hidup menetap di dasar perairan dapat menjadi bioindikator yang ideal. Sebuah penelitian menunjukkan bahwa spons mampumenjadi bioindikator pencemaran logam berat (As, Cd, Co, $\mathrm{Cu}, \mathrm{Fe}, \mathrm{Mn}$, dan $\mathrm{Ni}$ ) yang terjadi di Teluk Mannar, India (Rao et al., 2009). Selain itu, spons juga dapat digunakan sebagai bioindikator untuk minyak dan senyawa derivat dari polycyclic aromatic hydrocarbon (PAH) dan spons menunjukkan kemampuan yang lebih baik dalam mengakumulasikan senyawa tersebut daripada kerang coklat (Batista et al., 2013). Lebih lanjut, pencemaran limbah domestik yang banyak mengandung nutrien dan bakteri juga dapat dideteksi melalui spons baik itu dari kandungan senyawa kimia dan bakteri dalam jaringan maupun melimpahnya jenis spons tertentu di daerah itu (Chaves-Fonnegra et al., 2007). Meskipun demikian, tidak semua jenis spons bisa menjadi bioindikator, terutama logam berat yang sangat menggangu proses fisiologis dan bahkan merusak DNA spons maupun simbion yang ada (Efremova et al., 2002). 


\section{PENUTUP}

Spons di ekosistem terumbu karang mempunyai peranan ekologis yang sangat komplek. Spons dapat menjadi mediator antara faktor abiotik dan biotik sehingga memungkinkan siklus materi dan energi dalam ekosistem dapat terus berjalan. Selain itu spons menjadi penopang biodiversitas yang sangat efektif, yaitu kemampuannya berasosiasi dengan biota yang sangat beragam. Kelimpahan spons di suatu ekosistem terumbu karang perlu dimonitor perkembangannya mengingat fungsi ekologis dari terumbu karang kian menurun akibat faktor manusia ataupun karena faktor alam.

\section{DAFTAR PUSTAKA}

Batista, D., K. Tellini, A. H. Nudi, T. P. Massone, A. D. L. Scofield and A. de LR Wagener. 2013. Marine sponges as bioindicators of oil and combustion derived PAH in coastal waters. Marine environmental research 92: 234-243.

Bell, J. J. 2008. The functional roles of marine sponges. Estuarine, coastal and shelf science 79 (3): 341-353.

Chaves-Fonnegra, A., S. Zea and M. L. Gómez. 2007. Abundance of the excavating sponge Cliona delitrix in relation to sewage discharge at San Andrés Island, SW Caribbean, Colombia. Boletín de Investigaciones Marinas y Costeras-INVEMAR 36 (1): 63-78.
De Goeij, J. M., D. van Oevelen, M. J. A. Vermeij, R. Osinga, J. J. Middelburg, A. de Goeij and W. Admiraal. 2013. Surviving in a marine desert: The sponge loop retains resources within coral reefs. Science 342: 108-110.

De'ath, G., J. M. Lough and K. E. Fabricius. 2009. Declining coral calcification on the Great Barrier Reef. Science 323 (5910): 116-119.

Diaz, M. C. and K. Rützler. 2009. Biodiversity and abundance of sponges in Caribbean mangrove: indicators of environmental quality. Smithsonian Institution, Washington : $26 \mathrm{pp}$.

Efremova, S. M., B. A. Margulis, I. V. Guzhova, V. B. Itskovich, S. Lauenroth, W. E. Müller and H. C. Schröder 2002. Heat shock protein Hsp70 expression and DNA damage in Baikalian sponges exposed to model pollutants and wastewater from Baikalsk Pulp and Paper Plant. Aquatic Toxicology, 57 (4): 267-280.

Henkel, T. P. and J. R. Pawlik. 2011. Host specialization of an obligate sponge-dwelling brittlestar. Aquatic Biology 12 (1): 37-46.

Henkel, T. P. and J. R. Pawlik. 2011. Host specialization of an obligate sponge-dwelling brittlestar. Aquatic Biology 12 (1): 37-46. 
Hoffmann, F., H. Røy, K. Bayer, U. Hentschel, M. Pfannkuchen, F. Brümmer and D. De Beer, D. 2008. Oxygen dynamics and transport in the Mediterranean sponge Aplysina aerophoba. Marine biology 153 (6): 12571264.

Hooper, J. N. A. 2003. "Sponguide": guide to sponge collection and identification. Queensland Museum, Brisbane : 26 pp.

Jimenez, E. and M. Ribez. 2007. Sponges as a source of dissolved inorganic nitrogen: Nitrification by temperate sponges. Limnology and Oceanography 52 (3): 948-958.

Kaiser, K. and R. Benner. 2008. Major bacterial contribution to the ocean reservoir of detrital organic carbon and nitrogen. Limnology and Oceanography 53 (1): 99-112.

Maldonado, M., M. C. Carmona, Z. Velásquez, A. Puig, A. Cruzado, A. López and C. M. Young. 2005. Siliceous sponges as a silicon sink: an overlooked aspect of benthopelagic coupling in the marine silicon cycle. Limnology and Oceanography 50 (3): 799-809.

Manconi, R and R. Pronzato. 2008. Global diversity of sponges (Porifera: Spongillina) in freshwater. Hydrobiologia 595 (1): 27-33.
Marin, A. and M. D. López Belluga. 2005. Sponge coating decreases predation on the bivalve Arca noae. Journal of Molluscan Studies 71 (1): 1-6.

Marliave, J. B., K. W. Conway, D. M. Gibbs, A. Lamb and C. Gibbs. 2009. Biodiversity and rockfish recruitment in sponge gardens and bioherms of southern British Columbia, Canada. Marine Biology 156 (11): 22472254.

Nava, H. and J. L. Carballo. 2008. Chemichal and Mechanichal Bioerosion of Boring Sponss from Mexican Pacific Coral Reefs. The Journal of Experimental Biology 211 : $2827-2831$.

Pawlik, J. R., D. E. Burkepile and R. V. Thurber. 2016. A vicious circle? Altered carbon and nutrient cycling may explain the low resilience of Caribbean coral reefs. BioScience, 66 (6): 470-476.

Peters, K. J., C. D. Amsler, J. B. McClintock, R. W. van Soest and B. J. Baker. 2009. Palatability and chemical defenses of sponges from the western Antarctic Peninsula. Marine Ecology Progress Series 385: 77-85.

Peterson, B. J., C. M. Chester, F. J. Jochem and J. W. Fourqurean .2006. Potential role of sponge 
communities in controlling phytoplankton blooms in Florida Bay. Marine Ecology Progress Series 328: 93-103.

Rao, J. V., K. Srikanth, R. Pallela and T. G. Rao. 2009. The use of marine sponge, Haliclona tenuiramosa as bioindicator to monitor heavy metal pollution in the coasts of Gulf of Mannar, India. Environmental monitoring and assessment, 156: 1-4.

Ribeiro, S. M., E. P. Omena and G. Muricy. 2003. Macrofauna associated to Mycale microsigmatosa (Porifera Demospongiae) in Rio de Janeiro State, SE Brazil. Estuarine, Coastal and Shelf Science 57: 951-959.

Richter, C., M. Wunsch, M. Rasheed, I. KoÈtter and M. I. Badran. 2001. Endoscopic exploration of Red Sea coral reefs reveals dense populations of cavitydwelling sponges. Nature 413 (6857): 726.

Rutzler, K. 1990. Association between Caribbean sponges and photosynthetic organisms. International Sponge Conference: 455-466.

Rutzler, K., 1975. The role of burrowing sponges in bioerosion. Oecologia 19: 203-219.

Sabdono, A. 2011. Microbial symbionts in marine sponges: Marine natural product factory. Journal of Coastal Development, 11 (2):
57-61.

Schejter, L. and E. Spivak. 2005. Morphometric, sexual maturity, fecundity and epibiosis of the south American spider crab Libidoclaea granaria (Brachyura: Majoidea). Journal of the Marine Biological Association 85: 857-863.

Schmahl, G. P. 1990. Community structure and ecology of sponges associated with four southern Florida coral reefs. New perspectives in sponge biology. Smithsonian Institution Press, Washington: 376-383.

Schmidt, E. W. 2008. Trading molecules and tracking targets in symbiotic interactions. Nature chemical biology 4 (8): 466.

Puchner. 2013. Synaptid Sea Cucumbers! Big, Long \& Wormy or small and live in bunches on sponges! http://echinoblog.blogspot. co.id/2013/11/synaptids-longwormy-sea-cucumbers-some. html. Diakses pada February 2018 .

Tréguer, P. J. and C. L. De La Rocha. 2013. The world ocean silica cycle. Annual review of marine science, 5: 477-501.

Turon, X., M. Codina, I. Tarjuelo, M. J. Uriz, and M. A. Becerro. 2000. Mass recruitment of Ophiothrix fragilis (Ophiuroidea) on sponges: settlement patterns and post settlement dynamics. 
Marine Ecology Progress Series 200: 201-212.

Van Soest, R. W., N. Boury-Esnault, J. Vacelet, M. Dohrmann, D. Erpenbeck, N. De Voogd and J. N. Hooper. 2012. Global diversity of sponges (Porifera). PLoS one 7 (4): e35105.

Voultsiadou-Koukoura, E., A. Koukouras, and A. Eleftheriou. 1987. Macrofauna associated with the sponge Verongia aerophoba in the north Aegean Sea. Estuarine. Coastal and Shelf Science 24: 265-278.

Wilkinson, C. R. 1986. Productivity and abundance of large sponge populations on Flinders Reef flats, Coral Sea. Coral Reefs 5: 183-188.
Wilkinson, C. R. 1987. Interocean differences in size and nutrition of coral reef sponge populations. Science 236: 1654-1657.

Wulff, J. L. 2008. Collaboration among sponge species increases sponge diversity and abundance in a seagrass meadow. Marine Ecology 29 (2): 193-204.

Wulff, J. L. 1984. Sponge-mediated coralreef growth and rejuvenation. Coral Reefs 3: 157-163.

Wulff, J. L. and L. W. Buss. 1979. Do sponges help hold coral reefs together? Nature 281: 474-475. 